\section{Vietnam Journal of Agricultural Sciences}

\title{
Production Characteristics and Strategies for Adapting to the Impacts of Climate Change on Cassava Whiteflies and Viruses in Tanzania
}

\section{Oluwatosin Zacheus Aregbesola ${ }^{1,2,3}$, Veronica Nwakaego Uzokwe $^{3}$, Kolawole Adelekan Adeloye ${ }^{4}$, Carmelo Rapisarda ${ }^{1}$, Ole søgaard Lund ${ }^{2}$, Lene Sigsgaard ${ }^{2} \&$ James Peter Legg ${ }^{3}$}

'Department of Agriculture, Food and Environment, University of Catania, Catania CT 95123, Italy

${ }^{2}$ Department of Plant and Environmental Sciences, University of Copenhagen, København 1870, Denmark

${ }^{3}$ International Institute of Tropical Agriculture, Dar es Salaam 00000, Tanzania

${ }^{4}$ Obafemi Awolowo University, Ile-Ife 220001, Nigeria

\begin{abstract}
Cassava is Africa's most important food security crop and sustains about 700 million people globally. Survey interviews of 320 farmers in three regions of Tanzania to identify their production characteristics, and interviews with 20 international whitefly/virus experts were conducted to identify adaptation strategies to lessen the impacts of cassava whiteflies and viruses due to climate change in Tanzania. Structured and pre-tested interview schedules were conducted using a multistage sampling technique. Most of the farmers $(66.8 \%)$ produced cassava primarily for food, and relied mainly on their friends (43.8\%) and their farms (41.9\%) for cassava planting materials. Farmers significantly differed in their socioeconomic and production characteristics except for gender and access to extension support $(P<0.01)$. A significant association was found between extension support, sources of planting materials, and reasons for growing cassava with both the control of cassava viruses and the control of whiteflies by the farmers. A significantly higher number of farmers controlled cassava viruses $(38.1 \%)$ than cassava whiteflies (19.7\%). The adaptation strategies most recommended by experts were integrating pest and disease management programs, phytosanitation, and applying novel vector management techniques. The experts also recommended capacity building through the training of stakeholders, establishing monitoring networks to get updates on cassava pests and disease statuses, incorporating pest and disease adaptation planning into the general agricultural management plans, and developing climate change-pest/disease models for accessing the local and national level impacts that can facilitate more specific adaptation planning in order to enhance the farmers' adaptive capacities.
\end{abstract}

Received: September 11, 2020 Accepted: April 27, 2021

Correspondence to tosinaregbs@yahoo.com 


\section{Keywords}

Whiteflies, pest management, climate change, cassava

\section{Introduction}

Cassava is Africa's most important food security crop and sustains about 700 million people globally (FAO, 2013). Pests and diseases are the major constraints to cassava production. The most significant diseases of cassava are the two viral diseases cassava mosaic disease (CMD) and cassava brown streak disease (CBSD). The viruses causing both of these diseases are transmitted by the whitefly vector Bemisia tabaci (Gennadius) (Dubern, 1994; Maruthi et al., 2005). The continued expansion of cassava virus pandemics driven by super-abundant populations of $B$. tabaci is considered the greatest threat to cassava production in Africa (Legg et al., 2014a).

Agricultural systems in Africa are among the world's most vulnerable to the impacts of climate change (Niang et al., 2014; Adhikari et al., 2015). Tanzania farmers have been adopting different strategies in response to climate change impacts including diversifying crop production, diversifying to non-farm sectors of the economy, irrigation and water harvesting, applying fertilizer to boost yield, changing planting dates, growing short-season crops, growing droughtresistant crops, planting trees, rotating crops, using improved seeds and new crop varieties, and using mixed cropping systems (Mary \& Majule, 2009; Balama et al., 2013; Lyimo et al., 2013; Komba \& Muchapondwa, 2018). Research reports have demonstrated that the responses of cassava viruses and their whitefly vector to climate change will vary spatially depending on the prevailing conditions (Bellotti et al., 2012; Jarvis et al., 2012). Gamarra et al. (2016), Aregbesola (2018), and Aregbesola et al. (2019; 2020) suggested that climate change will lead to an increase in the population growth of $B$. tabaci for regions in East, Central, and Southern Africa. Similarly, Campo et al. (2011) identified the African rift valley as a hotspot for cassava pests and diseases (including B. tabaci, CMD, and CBSD) considering future climate scenarios. This makes it necessary to plan and implement strategies for adapting to the predicted increased burden of cassava viruses and whiteflies on cassava production caused by climate change.

Strategies for adapting to the impacts of climate change on cassava whiteflies and viruses, and measures needed to enhance the adaptive capacity of farmers to reduce the impacts of cassava whiteflies and viruses due to climate change have not been investigated and remain poorly understood. This study, therefore, aimed at filling these gaps. The objectives of the study were to: evaluate cassava farmers' production characteristics, explore potential adaptation strategies to counter the impacts of cassava whiteflies and viruses due to climate change, and identify relevant measures for enhancing the adaptive capacity of farmers on their farms, at regional or national levels, so that they can respond better to changes in crop damages caused by cassava whiteflies and the viruses that they transmit.

\section{Materials and Methods}

\section{Description of the study sites}

The study was conducted in Kigoma, Pwani, and Zanzibar regions of Tanzania. From each region, the selected districts were Kakonko, Mkuranga, and Unguja respectively. Agriculture accounts for about $29.1 \%$ of the national gross domestic product (GDP), provides $70 \%$ of the raw materials used by industries, and $30 \%$ of the export earnings of Tanzania (Chongela, 2015). The climate of Tanzania is characterized by a long dry spell from May to October, followed by a period of low rainfall. Tanzania experiences a main rainy season from March to June and a short rainy season from October to December (URT, 2012a). The Kigoma region is located in northwest Tanzania, close to Lake Tanganyika. It is covered by coordinates between $29.5^{\circ}-31.5^{\circ}$ to the East, and $3.5^{\circ}-6.5^{\circ}$ to the South. Unguja is one of the islands of Zanzibar located in the Indian Ocean, around the coordinates $39.4^{\circ}$ South - 6.1 East ${ }^{\circ}$. Mkuranga is a district in the Pwani Region of Tanzania. It is to the south of Dar es Salaam, and shares its eastern and western borders with the Indian Ocean and Kisarawe District, respectively. It is bordered on the south 
by Rufiji District (URT, 2012b). The study sites are depicted in Figure 1.

\section{Data collection}

A methodological triangulation technique was employed in the study (Olsen, 2004). This involved farmer interviews, direct farm observations, expert interviews, follow-up visits, and desk research. The desk research involved the compilation of secondary data through a review of literature on the impacts of climate change on agriculture, the management of cassava pests and diseases, strategies for adapting to the impacts of climate change on pests and diseases, and enhancing the adaptive capacity of farmers to minimize the impacts of climate change.

A semi-structured questionnaire was used to collect information on the socio-economic characteristics of the farmers relating to their age, years of formal education, gender, occupation besides farming, household size, etc. Additional information was also collected on the production characteristics of the farmers including their challenges, reasons for cassava production, sources of cassava planting materials, methods used to control cassava whiteflies and viruses, and use of agricultural extension support.

For the expert survey, the questionnaire intended to collect information on expert opinions on adaptation strategies to reduce the impacts of climate change on cassava virus disease pandemics in Africa and ways to enhance the adaptive capacity of farmers. Climate change adaptation strategies and measures to enhance the adaptive capacity were rated on a 4-point scale with $1=$ Not recommended, $2=$ Neutral, 3 $=$ Recommended, and $4=$ Strongly recommended. Questionnaires were pre-tested and updated based on expert advice before the actual survey.

\section{Surveys}

Sampling was based on information and expertise on cassava production at the

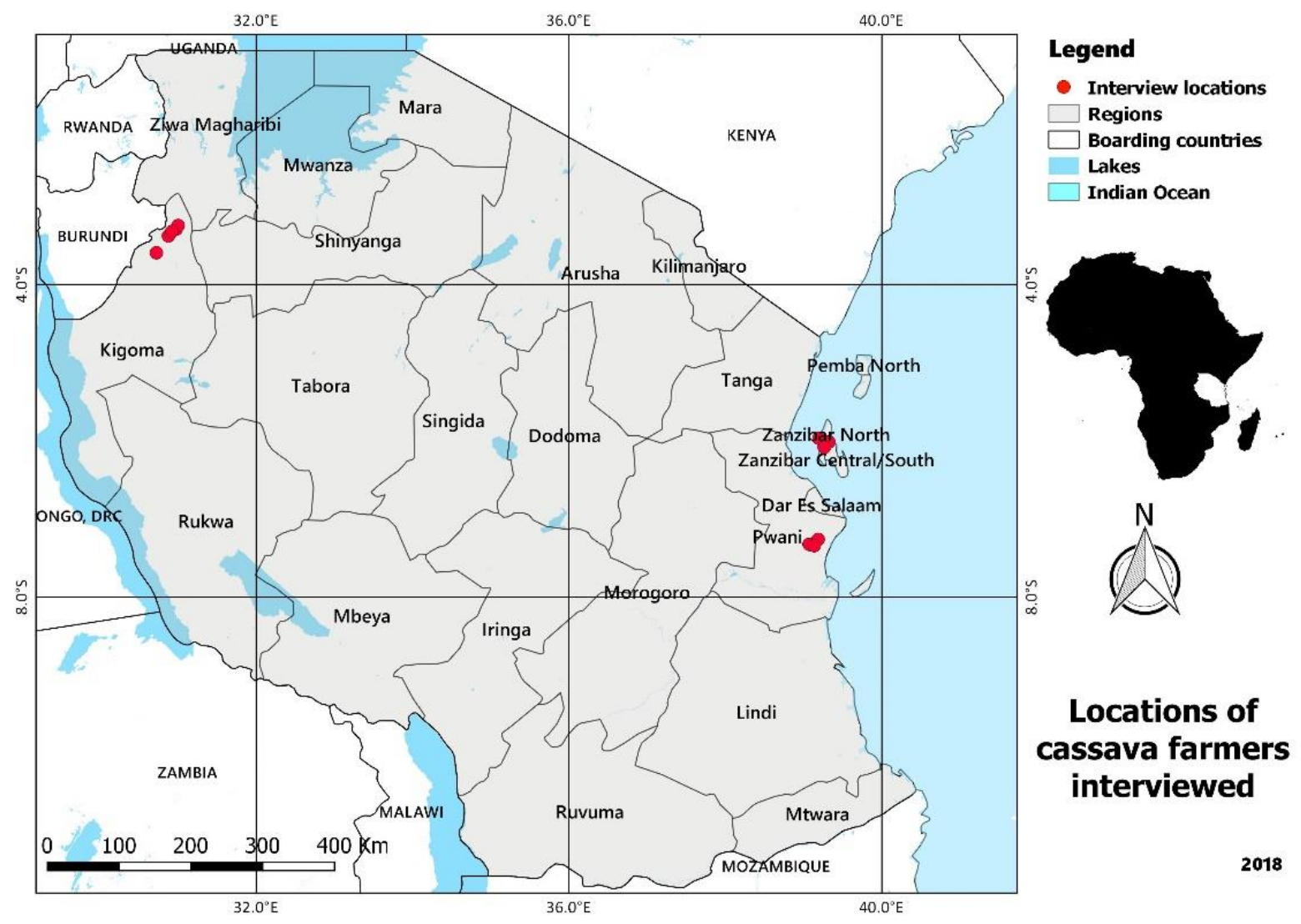

Figure 1. Locations of the farmers interviewed 
International Institute of Tropical Agriculture (Tanzania); and a desk review of cassava pest problems in Tanzania (Legg \& Raya, 1998; Ndyetabula et al., 2016). A multi-stage sampling procedure with three phases was used in selecting respondents for the study. The first phase involved the selection of three districts from three major cassava growing regions in Tanzania. The selected cassava growing regions were Kigoma, Pwani, and Zanzibar, while the selected districts were Kakonko, Mkuranga, and Unguja located in each region, respectively. The three regions were selected because they are major cassava growing areas and represent different cassava whitefly and virus situations. Villages within each district were subsequently selected using a cluster sampling technique based on cassava production information from the agricultural extension officers in charge of each district. The last sampling stage involved a random household selection from a list maintained by the resident agricultural extension agent in each village. Overall, four villages were chosen from each district, with 25 respondents per village in Kakonko and Unguja, and 30 respondents per village in Mkuranga, making a total of 320 respondents. Out of the 320 questionnaires from the farmers' survey, 318 were suitable for data analysis.

The farmers' survey was conducted in the local language (Swahili) for easy comprehension of the questions. Questionnaires were administered through face-to-face interviews by trained researchers and extension agents. The enumerators were experienced researchers and agricultural extension officers who were very familiar with the respective study areas. Recruitment of researchers and extension officers the farmers were conversant with facilitated effective interactions with the farmers. The services of four enumerators (both men and women) were used in each study area.

Survey interviews of experts were used to investigate the transforming structures and processes that could enhance each farmers' adaptive capacity and also to identify useful adaptation strategies on the farms and at regional or national levels. First, a desk review of research on climate change adaptation, adaptive strategies of farmers to crop pests and adaptation strategies to crop pests was conducted. From the review, key aspects related to enhancing the adaptive capacity to crop pests and diseases, and possible adaptation strategies to the potential impacts of climate change on crop pests and diseases were identified. Based on the desk research, we then developed our question items, which were subjected to further review and scrutiny by experts on the subjects before the final versions of the questionnaires were prepared. The expert survey was conducted as both an e-mailed survey and a paper survey. For the expert survey, a database of publications relating to cassava virus diseases and whiteflies, and climate change plant disease and insect studies was created. From this database, a list of scientists was compiled based on publication records, and electronic copies of the survey were sent to a total of 80 scientists. Due to the relatively low response rate, the number was augmented by administering a printed copy of the survey to selected experts at the $2^{\text {nd }}$ International Whitefly Symposium held in Arusha, Tanzania. In all, 20 questionnaires were processed for further analysis.

\section{Data analysis}

Responses from the questionnaires were encoded and analyzed using SPPS ${ }^{\circledR}$ (IBM $®$ SPSS ${ }^{\circledR}$ statistics version 20 . Based on the nature of the data, dichotomous variables were analyzed using the binomial exact test, while other categorical variables were analyzed using the chi-square test at $P=0.05$. The chi-square test was also used to test the association between production characteristics and the control of both whiteflies and cassava viruses. Furthermore, the McNemar test was used to compare the proportion of farmers who controlled cassava viruses to the proportion of farmers who controlled whiteflies. Data on the adaptation strategies and building adaptive capacity were subjected to either the chi-square test or binomial test $(P=0.05)$. 


\section{Results}

\section{Production characteristics of cassava farmers}

The percentage of male cassava farmers interviewed was not significantly higher than females. Cassava farmers surveyed in the three locations had a mean age of $44.7 \pm 12.8$ (SD) years, though farmers in Unguja tended to be older than farmers in the other locations. The majority of the farmers completed primary education, whereas a good number of respondents from Unguja completed secondary education. Occupations besides farming differed significantly across the respondents (Table 1). Overall, almost half of the farmers interviewed had no other occupation apart from farming. Some also engaged in petty trading. Incomes from cassava production and other activities were low. The mean off-farm income per annum for the three locations was USD $442.68 \pm$ 1513.84, while the mean income from cassava production per annum was USD $277.10 \pm$ 446.54. More than $80 \%$ of the farmers reported making less than USD 500 per annum from both cassava production and non-farm activities, respectively (Table 1).

Farmers in Mkuranga and Unguja tended to be more experienced than farmers in Kakonko. Considering all the locations, the mean number of years in cassava cultivation was 12.6 years. Land areas put into cassava cultivation were small. Over seventy-seven percent (77.4\%) of the farmers grew cassava on less than 1ha (Table 2). On average, farmers in Kakonko put more land area into cassava cultivation, while the mean land area used for growing cassava was $0.28 \pm 0.58 \mathrm{ha}$. Almost all the farmers (98.0\%) grew other crops. The highest percentage of farmers that controlled cassava viruses was recorded in Unguja (67.0\%), while the least was recorded in Mkuranga (7.1\%). Considering all the locations, $38.1 \%$ (of 318 farmers) controlled cassava viruses, while only $19.7 \%$ of the 318 farmers controlled cassava whiteflies (Table 2). No farmer reported controlling cassava whiteflies in Kakonko, while more farmers in Unguja (58.0\%) reported controlling cassava whiteflies than Mkuranga $(3.5 \%)$. The frequencies of farmers who got extension support did not significantly differ from those who did not. Table 2 shows that more farmers in Unguja received extension support than farmers in other locations. The majority of the respondents got their planting materials from their friends and the previous seasons, and significant differences existed among the sources of planting materials (Table 2). Generally, the primary motivation for cassava cultivation was for food. However, farmers in Unguja and Kakonko also showed a higher inclination toward cultivating cassava for-profit compared to farmers in Mkuranga. The reasons for growing cassava differed significantly among the interviewed farmers (Table 2).

A significant association was found between extension support, sources of planting materials, and reasons for growing cassava for both the variables of controlling cassava viruses and controlling whiteflies. Furthermore, experience in cassava production, cassava farm size, nonfarm income, extension support, and the use of chemicals to control whiteflies were also significantly associated with the control of cassava whiteflies, but not the control of viruses (Table 3).

\section{Current cassava whitefly and virus control measures employed by the farmers}

Most farmers did not control cassava whiteflies and viruses, although more farmers controlled cassava viruses than whiteflies (Table 4). Among the farmers who reported controlling cassava whiteflies and viruses, various approaches were reported. For control of cassava whiteflies, farmers mainly applied farm sanitation and roguing. A few farmers reported using resistant/tolerant/improved varieties to control whiteflies. The categories of whitefly control methods reported by farmers occurred with different probabilities $(P<0.01)$ (Table 4). For control of cassava viruses, the farmers used roguing, clean cassava planting materials, and resistant varieties. However, the proportions of farmers who applied these control methods were very low compared to the total number of respondents. Additionally, the farmers did not use chemicals to control cassava whiteflies (Table 2). Significant differences occurred in the cassava virus control methods reported by the farmers $(P<0.01)$ (Table 4). The frequencies of farmers who controlled cassava whiteflies 
Table 1. Socio-economic characteristics of the cassava farmers

\begin{tabular}{|c|c|c|c|c|c|}
\hline $\begin{array}{c}\text { Variables } \\
\text { (n) }\end{array}$ & $\begin{array}{l}\text { Kakonko } \\
(100)\end{array}$ & $\begin{array}{c}\text { Mkuranga } \\
\text { (118) }\end{array}$ & $\begin{array}{l}\text { Unguja } \\
(100)\end{array}$ & $\begin{array}{l}\text { Total } \\
(318)\end{array}$ & $P$-value \\
\hline & $F(\%)$ & $F(\%)$ & $F(\%)$ & $F(\%)$ & \\
\hline Gender & & & & & 0.911 \\
\hline Male & $56(56.0)$ & $76(65.0)$ & $28(28.0)$ & $160(50.5)$ & \\
\hline Female & $44(44.0)$ & $41(35.0)$ & $72(72.0)$ & $157(49.5)$ & \\
\hline Age $(\text { years })^{x}$ & $40.42 \pm 10.66$ & $45.78 \pm 10.49$ & $47.97 \pm 10.49$ & $44.8 \pm 12.9$ & $<0.001$ \\
\hline $20-30$ & $19(19.0)$ & $26(22.2)$ & $6(6.1)$ & $51(16.1)$ & \\
\hline $31-40$ & $65(65.0)$ & $44(37.6)$ & $58(58.6)$ & $167(52.8)$ & \\
\hline$>40$ & $16(16.0)$ & $47(40.17)$ & $35(25.4)$ & $98(31.1)$ & \\
\hline Level of education & & & & & $<0.001$ \\
\hline No formal education & $2(2.0)$ & $33(28.0)$ & $29(29.0)$ & $64(20.1)$ & \\
\hline Primary & $88(88.0)$ & $76(64.4)$ & $28(28.0)$ & $192(60.4)$ & \\
\hline Secondary & $9(9.0)$ & $9(7.6)$ & $41(41.0)$ & $59(18.6)$ & \\
\hline Tertiary & $1(1.0)$ & $0(0.0)$ & $2(2.0)$ & $3(0.9)$ & \\
\hline $\begin{array}{l}\text { Occupation besides } \\
\text { farming }\end{array}$ & & & & & $<0.001$ \\
\hline Petty trade & $25(25.0)$ & $45(38.5)$ & $39(39.4)$ & $109(34.5)$ & \\
\hline Retiree & $2(2.0)$ & $1(0.9)$ & $3(3.0)$ & $6(1.9)$ & \\
\hline Artisan & $12(12.0)$ & $2(1.7)$ & $6(6.1)$ & $20(6.3)$ & \\
\hline Others & $6(6.0)$ & $7(6.0)$ & $7(7.1)$ & $20(6.3)$ & \\
\hline Formal employment & $0(0.0)$ & $0(0.0)$ & $15(15.2)$ & $15(4.7)$ & \\
\hline None & $55(55.0)$ & $62(53.0)$ & $29(29.3)$ & $146(46.2)$ & \\
\hline $\begin{array}{l}\text { Non-farm } \\
\text { income/year (USD) } x\end{array}$ & $159.46 \pm 557.95$ & $145.68 \pm 289.91$ & $1076.36 \pm 2517.09$ & $442.68 \pm 1513.84$ & $<0.001$ \\
\hline$<500$ & $92(92.0)$ & $108(91.5)$ & $61(61.0)$ & 261 (82.1) & \\
\hline $500-<2000$ & $7(7.0)$ & $10(8.5)$ & $28(28.0)$ & $45(14.1)$ & \\
\hline$>2000$ & $1(1.0)$ & $0(0.0)$ & $11(11.0)$ & $12(3.8)$ & \\
\hline $\begin{array}{l}\text { Income from } \\
\text { cassava/year (USD) } \\
x\end{array}$ & $197.26 \pm 377.32$ & $289.72 \pm 331.35$ & $342.06 \pm 596.20$ & $277.10 \pm 446.54$ & $<0.001$ \\
\hline$<500$ & $95(95.0)$ & $103(87.3)$ & $83(83.0)$ & $281(88.4)$ & \\
\hline $500-<2000$ & $34(4.0)$ & $14(11.9)$ & $14(14.0)$ & $32(10.0)$ & \\
\hline$>2000$ & $1(1.0)$ & $1(0.8)$ & $3(3.0)$ & $5(1.6)$ & \\
\hline
\end{tabular}

Note: $n=$ number of respondents. $P$-value based on one sample chi-square test except otherwise indicated. ${ }^{x}$ means of variables on ratio scale are presented. F represents the frequency of interviewed respondents.

Source: Field survey (2016 and 2017). 
Table 2. Production characteristics of the cassava farmers

\begin{tabular}{|c|c|c|c|c|c|}
\hline $\begin{array}{c}\text { Variables } \\
\text { (n) }\end{array}$ & $\begin{array}{c}\text { Kakonko } \\
(100)\end{array}$ & $\begin{array}{c}\text { Mkuranga } \\
\text { (118) }\end{array}$ & $\begin{array}{l}\text { Unguja } \\
(100)\end{array}$ & $\begin{array}{l}\text { Total } \\
(318)\end{array}$ & $P$-value \\
\hline & $\mathrm{F}(\%)$ & $\mathrm{F}(\%)$ & $\mathrm{F}(\%)$ & $\mathrm{F}(\%)$ & \\
\hline $\begin{array}{l}\text { Experience in cassava production } \\
\text { (years) } \mathrm{X}\end{array}$ & $6.68 \pm 6.60$ & $13.97 \pm 9.83$ & $17.02 \pm 10.70$ & $12.57 \pm 10.1$ & $<0.001$ \\
\hline $1-<5$ & $53(53.0)$ & $21(19.8)$ & $10(10.1)$ & $84(27.5)$ & \\
\hline $5-<15$ & $32(32.0)$ & $34(32.1 .8)$ & $31(31.3)$ & $97(31.8)$ & \\
\hline$>15$ & $15(15.0)$ & $51(48.1)$ & $58(58.6)$ & $124(40.7)$ & \\
\hline Cassava farm size (ha) $X$ & $0.91 \pm 0.68$ & $0.77 \pm 0.33$ & $0.72 \pm 0.50$ & $0.80 \pm 0.52$ & $<0.001$ \\
\hline$<1$ & $64(64.0)$ & $95(81.2)$ & $84(86.6)$ & $243(77.4)$ & \\
\hline $1-<4$ & $35(35.0)$ & $22(18.8)$ & $13(13.4)$ & $70(22.3)$ & \\
\hline$>4$ & $1(1.0)$ & $0(0.0)$ & $0(0.0)$ & $1(0.3)$ & \\
\hline Grow other crops (\%) & & & & & $<0.001 a$ \\
\hline Yes & $100.0(100)$ & $114(96.6)$ & $97(98.0)$ & $311(98.1)$ & \\
\hline No & $0(0.0)$ & $4(3.4)$ & $2(2.0)$ & $6(1.9)$ & \\
\hline Control whiteflies (\%) & & & & & $<0.001 \mathrm{a}$ \\
\hline Yes & $0(0.0)$ & $4(3.5)$ & $58(58.0)$ & $62(19.7)$ & \\
\hline No & $100.0(100)$ & $111(96.5)$ & $42(42.0)$ & $253(80.3)$ & \\
\hline Control cassava viruses (\%) & & & & & $<0.001 a$ \\
\hline Yes & $44(44.0)$ & $8(7.1)$ & $67(67.0)$ & $119(38.1)$ & \\
\hline No & $56(56.0)$ & $104(92.9)$ & $33(33.0)$ & $193(61.9)$ & \\
\hline Got extension support (\%) & & & & & $0.160 a$ \\
\hline Yes & $38(38.8)$ & $22(18.6)$ & $85(85.0)$ & $145(45.9)$ & \\
\hline No & $60(61.2)$ & $96(81.4)$ & $15(15.0)$ & $171(54.1)$ & \\
\hline $\begin{array}{l}\text { Used chemicals to control } \\
\text { whiteflies (\%) }\end{array}$ & & & & & $<0.001 \mathrm{a}$ \\
\hline Yes & $0(0.0)$ & $1(0.8)$ & $1(1.0)$ & $2(0.6)$ & \\
\hline No & $100.0(100)$ & $117(99.2)$ & $99(99.0)$ & $316(99.4)$ & \\
\hline Sources of planting materials\# & & & & & $<0.001$ \\
\hline Friends & $60(56.6)$ & $49(41.9)$ & $53(36.1)$ & $162(43.8)$ & \\
\hline Previous own crop & $42(39.6)$ & $65(55.6)$ & $48(32.7)$ & $155(41.9)$ & \\
\hline Extension service & $0(0.0)$ & $0(0.0)$ & $7(4.8)$ & $7(1.9)$ & \\
\hline Research institute & $4(3.8)$ & $0(0.0)$ & $38(25.9)$ & $42(11.4)$ & \\
\hline Market & $0(0.0)$ & $3(2.6)$ & $1(0.7)$ & $4(1.1)$ & \\
\hline Motivation for growing cassava\# & & & & & $<0.001$ \\
\hline Food & $52(47.7)$ & $77(85.6)$ & $88(71.0)$ & $217(67.2)$ & \\
\hline Profit & $57(52.3)$ & $13(14.4)$ & $34(27.4)$ & $104(32.2)$ & \\
\hline Leisure & $0(0.0)$ & $0(0.0)$ & $0(0.0)$ & $0(0.0)$ & \\
\hline Interest & $0(0.0)$ & $0(0.0)$ & $2(1.6)$ & $2(0.6)$ & \\
\hline No choice & $0(0.0)$ & $2(2.2)$ & $0(0.0)$ & $2(0.6)$ & \\
\hline
\end{tabular}

Notes: $n=$ number of respondents. $P$-value based on one sample chi-square test except otherwise indicated. a $-P$-values based on one sample binomial test. $X$ means of variables on a ratio scale are presented. \# multiple responses possible. $F$ represents the frequency of interviewed respondents. Source: Field survey (2016 and 2017). 
Table 3. Association between production characteristics and control of cassava viruses and whiteflies

\begin{tabular}{|c|c|c|c|c|c|c|}
\hline \multirow{2}{*}{ Production Characteristics } & \multicolumn{3}{|c|}{ Cassava viruses } & \multicolumn{3}{|c|}{ Cassava whiteflies } \\
\hline & Chi-Square & d.f & $P$-value & Chi-Square & d.f & $P$-value \\
\hline Experience in cassava production (years) & 30.121 & 31 & 0.511 & 54.957 & 31 & 0.005 \\
\hline Size of cassava farm (ha) & 30.717 & 18 & 0.031 & 34.722 & 18 & 0.010 \\
\hline Income from cassava production (USD) & 80.535 & 85 & 0.617 & 77.918 & 85 & 0.694 \\
\hline Non-farm income (USD) & 48.863 & 41 & 0.186 & 95.987 & 41 & $<0.001$ \\
\hline Produce other crops apart from cassava (\%) & 2.089 & 1 & 0.148 & 0.713 & 1 & 0.399 \\
\hline Received extension advice (\%) & 84.473 & 1 & $<0.001$ & 40.903 & 1 & $<0.001$ \\
\hline Use chemicals to control whiteflies (\%) & 0.120 & 1 & 0.729 & 8.213 & 1 & 0.004 \\
\hline Sources of planting materials & 47.174 & 8 & $<0.001$ & 76.482 & 8 & $<0.001$ \\
\hline Reasons for growing cassava & 41.194 & 3 & $<0.001$ & 36.981 & 3 & $<0.001$ \\
\hline
\end{tabular}

Note: $n=318$, $P$-value based on chi-square test.

Source: Field survey (2016 and 2017).

Table 4. Whitefly and virus control methods reported by the farmers

\begin{tabular}{lcc}
\hline \multicolumn{1}{c}{ Whitefly control practices } & $F(\%)$ & Virus control practices \\
\hline Farm sanitation including weeding & $23(7.3)$ & Early planting \\
Improved varieties & $3(0.9)$ & Planting clean seeds \\
Resistant varieties & $3(0.9)$ & Improved varieties \\
Tolerant varieties & $2(0.6)$ & Resistant varieties \\
Roguing & $11(3.5)$ & Roguing \\
Using ash & $1(0.3)$ & Using ash \\
No response & $5(1.6)$ & Weeding \\
No control & $270(84.9)$ & No response \\
$P$-value & & No control \\
\hline
\end{tabular}

Note: $n=318$, P-value based on one sample chi-square test. F represents the frequency of interviewed respondents.

Table 5. Comparison of farmers who controlled cassava whiteflies and viruses across all locations

\begin{tabular}{|c|c|c|c|c|c|}
\hline \multirow{2}{*}{ Variables } & Kakonko & Mkuranga & Unguja & Total & $P$-value \\
\hline & $F(\%)$ & $F(\%)$ & $F(\%)$ & $F(\%)$ & \\
\hline Control whiteflies (\%) & $0(0.0)$ & $4(3.5)$ & $58(58.0)$ & $62(19.7)$ & $<0.001$ \\
\hline Control cassava viruses (\%) & $44(44.0)$ & $8(7.1)$ & $67(67.0)$ & $119(38.1)$ & \\
\hline
\end{tabular}

Note: $P$-value based on the McNemar test ${ }^{*}$ significant at $P=0.05$. F represents the frequency of interviewed respondents. Source: Field survey (2016 and 2017).

differed significantly from the farmers who did not control cassava whiteflies $(P<0.01)$ (Table 5).

A qualitative evaluation of the socioeconomic and production characteristics of the farmers showed that some of the problems recorded in the study areas could influence their adaption to the impacts of climate change on cassava whiteflies and viruses.

\section{Description of experts}

The majority $(95.0 \%)$ of the cassava pest and disease experts surveyed were male, and their most common disciplines were entomology and plant virology $(30.0 \%)$. Furthermore, they had an 
Table 6. Distribution of the cassava pest and disease experts by selected professional characteristics

\begin{tabular}{|c|c|c|c|}
\hline Variables & Frequency & Percentages & Mean \\
\hline \multicolumn{4}{|l|}{ Sex } \\
\hline Male & 19 & 95.0 & \\
\hline Female & 1 & 5.0 & \\
\hline \multicolumn{4}{|l|}{ Specialization } \\
\hline Entomology & 7 & 35.0 & \\
\hline Plant breeding & 2 & 10.0 & \\
\hline Plant molecular biology & 1 & 5.0 & \\
\hline Plant virology & 6 & 30.0 & \\
\hline Vector entomology & 4 & 20.0 & \\
\hline \multicolumn{4}{|l|}{ Years of experience as an expert } \\
\hline Below 10 & 5 & 25.0 & \\
\hline $11-20$ & 8 & 40.0 & $19.1 \pm 9.4$ \\
\hline Above 20 & 7 & 35.0 & \\
\hline \multicolumn{4}{|c|}{$\begin{array}{l}\text { Scientific meetings on cassava and climate } \\
\text { change attended }\end{array}$} \\
\hline Below 5 & 18 & 90.0 & \\
\hline $6-10$ & 2 & 10.0 & $3.3 \pm 2.5$ \\
\hline \multicolumn{4}{|c|}{ Membership of professional bodies } \\
\hline Below 5 & 17 & 85.0 & \\
\hline $6-10$ & 3 & 15.0 & $2.4 \pm 1.9$ \\
\hline
\end{tabular}

Note: $n=20$. Source: Field survey (2016 and 2017)

average of $19.1 \pm 9.4$ years of experience as experts in their various fields (Table 6).

Adaptive strategies and enhancing the adaptive capacity to reduce the impacts of cassava whiteflies and viruses due to climate change

The results showed that integrating pest and disease management programs ranked the highest as a proposed adaptive strategy to control cassava pests and diseases, followed by phytosanitation and applying novel vector management techniques, while increasing offfarm income was ranked lowest (Table 7).

Experts were unanimous in their recommendation of capacity building through training of stakeholders, establishing monitoring networks, and incorporating pest and disease adaptation planning into agricultural management plans, as a majority of them strongly recommended these approaches for building the adaptive capacity of farmers to decreasing the potential impacts of cassava pests and diseases due to climate change (Table 8).

\section{Discussion}

\section{Production characteristics}

Our results suggested that the farmers have diversified cropping systems that could make them resilient to the impacts of cassava whiteflies and viruses due to climate change, which support previous reports from Tanzania and other African countries (Oleke et al., 2011; Makate et al., 2016; Kissoly et al., 2018). Access to agricultural extension services was relatively low in two (Mkuranga and Kakonko) of the three study locations. This agrees with the reports for Dodoma and Unguja (Tanzania) by Anderson (2017) and URT (2012a), respectively. Increasing access of African farmers to agricultural information through mobile phone services is likely to augment the work of extension in the years ahead, and the use of mobile phones for the exchange of agricultural 
Table 7. Distribution of experts by adaptation strategies to cassava whitefly and viruses

\begin{tabular}{|c|c|c|c|c|c|c|}
\hline Adaptation strategies & $\begin{array}{c}\text { NR } \\
F(\%)\end{array}$ & $\begin{array}{c}\text { Neutral } \\
F(\%)\end{array}$ & $\begin{array}{c}R \\
F(\%)\end{array}$ & $\begin{array}{c}\text { SR } \\
F(\%)\end{array}$ & Mean & $P$-value \\
\hline $\begin{array}{l}\text { Integrating pest and disease } \\
\text { management programs }\end{array}$ & $0(0.0)$ & $0(0.0)$ & $7(35.0)$ & $13(65.0)$ & 3.65 & $0.263^{\ddagger}$ \\
\hline Phytosanitation & $1(5.0)$ & $2(10.0)$ & $6(30.0)$ & $11(55.0)$ & 3.35 & 0.006 \\
\hline $\begin{array}{l}\text { Controlling whiteflies and viruses } \\
\text { with resistant varieties }\end{array}$ & $1(5.0)$ & $0(0.0)$ & $10(50.0)$ & $9(45.0)$ & 3.35 & 0.026 \\
\hline Controlling whiteflies with biocontrol & $0(0.0)$ & $1(5.0)$ & $11(55.0)$ & $8(40.0)$ & 3.35 & 0.019 \\
\hline Diversifying crop production & $0(0.0)$ & $3(15.0)$ & $9(45.0)$ & $8(40.0)$ & 3.25 & 0.212 \\
\hline $\begin{array}{l}\text { Applying novel vector management } \\
\text { techniques }\end{array}$ & $1(5.0)$ & $3(15.0)$ & $11(55.0)$ & $5(25.0)$ & 3.00 & 0.011 \\
\hline Adjusting planting dates & $2(10.0)$ & $5(25.0)$ & $13(65.0)$ & $0(0.0)$ & 2.55 & 0.008 \\
\hline Controlling whiteflies with chemicals & $9(45.0)$ & $6(30.0)$ & $5(25.0)$ & $0(0.0)$ & 1.80 & 0.522 \\
\hline Shifting from cassava to other crops & $13(65.0)$ & $6(30.0)$ & $1(5.0)$ & $0(0.0)$ & 1.40 & 0.004 \\
\hline
\end{tabular}

Note: $n=20$. NR - Not Recommended, $R$ - Recommended, $S R-S t r o n g l y ~ R e c o m m e n d e d . ~{ }^{\ddagger} P$-value based on one sample binomial test, all other $P$-values are based on one sample chi-square test. $F$ represents the frequency of interviewed respondents.

Source: Field survey (2016 and 2017).

Table 8. Distribution of respondents by measures to enhance adaptive capacity

\begin{tabular}{|c|c|c|c|c|c|c|}
\hline $\begin{array}{l}\text { Measures to enhance adaptive } \\
\text { capacity }\end{array}$ & $\begin{array}{c}\text { NR } \\
F(\%)\end{array}$ & $\begin{array}{l}\text { Neutral } \\
F(\%)\end{array}$ & $\begin{array}{c}\mathrm{R} \\
\mathrm{F}(\%)\end{array}$ & $\begin{array}{c}\mathrm{SR} \\
\mathrm{F}(\%)\end{array}$ & Mean & $P$-value \\
\hline $\begin{array}{l}\text { Capacity building through training of } \\
\text { stakeholders from farms to the } \\
\text { regional levels }\end{array}$ & $0(0.0)$ & $0(0.0)$ & $6(30.0)$ & $14(70.0)$ & 3.70 & $0.115^{\ddagger}$ \\
\hline $\begin{array}{l}\text { Establish monitoring networks } \\
\text { (through coordinated national and } \\
\text { international surveillance and } \\
\text { monitoring programs to get updates } \\
\text { on new developments) }\end{array}$ & $0(0.0)$ & $0(0.0)$ & $8(40.0)$ & $12(60.0)$ & 3.60 & $0.503^{\ddagger}$ \\
\hline $\begin{array}{l}\text { Incorporating pest and disease } \\
\text { adaptation planning into the general } \\
\text { agricultural management plans at } \\
\text { both national and regional levels }\end{array}$ & $0(0.0)$ & $0(0.0)$ & $8(40.0)$ & $12(60.0)$ & 3.60 & $0.503^{\ddagger}$ \\
\hline $\begin{array}{l}\text { Development of climate change- } \\
\text { pest/disease models for accessing } \\
\text { local and national level impact that } \\
\text { can facilitate more specific adaptation } \\
\text { planning }\end{array}$ & $0(0.0)$ & $1(5.0)$ & $12(60.0)$ & $7(35.0)$ & 3.30 & 0.011 \\
\hline $\begin{array}{l}\text { Assess adaptation needs (including } \\
\text { technological needs) through } \\
\text { stakeholder (farmers, research } \\
\text { community, and governments) }\end{array}$ & $1(5)$ & $2(10.0)$ & $10(50.0)$ & $7(35.0)$ & 3.20 & 0.157 \\
\hline Enforcing quarantine and regulations & $1(5.0)$ & $2(10.0)$ & $10(50.0)$ & $7(35.0)$ & 3.15 & 0.013 \\
\hline $\begin{array}{l}\text { Improve access to credit and } \\
\text { insurance (to make improved and } \\
\text { clean planting material affordable) }\end{array}$ & $2(10.0)$ & $3(15.0)$ & $12(60.0)$ & $3(15.0)$ & 2.80 & 0.004 \\
\hline
\end{tabular}

Notes: $n=20 . N R-$ Not Recommended, $R$ - Recommended, SR-Strongly Recommended. ${ }^{\ddagger} P$-value based on one sample binomial test, all other $P$-values are based on one sample chi-square test. F represents the frequency of interviewed respondents. Source: Field survey (2016 and 2017). 
information is increasing in Africa (Krone et al., 2014; Asa \& Uwem, 2017). Osei et al. (2009) and Houngue et al. (2018) observed that the primary sources of planting materials used for cassava cultivation by smallholder farmers were neighbors and their own farms, which agrees with our report from Tanzania. Oyekanmi \& Okeleye (2007) also reported food and economic benefits as the major reasons for cassava production in Nigeria.

An important finding about cassava pest and disease management among the interviewed farmers was that the majority of them controlled neither cassava whiteflies nor viruses. Consistent with these findings, a recent report from the Republic of Benin suggested that farmers do not control CMD even when CMD is observed in their fields (Houngue et al., 2018). This might be related to the small-scale and low input cropping systems employed for cassava production in most cassava-growing areas in sub-Saharan Africa (SSA). For the control of cassava viruses, the planting of clean stem cuttings and the use of resistant varieties are among the best control options (Legg \& Fauquet, 2004; Legg et al., 2015), and our study indicated that many farmers that control cassava viruses depend on these methods.

This study also showed that several factors are associated with whether a farmer controls cassava whiteflies and viruses, which agree with findings from other crop production systems (Omolehin et al., 2007; Uwagboe et al., 2012). Among these factors, access to extension services, the reasons for cassava production, and the sources of planting materials were significantly associated with the control of both whiteflies and viruses. This suggests that they are important factors that could explain whether a farmer controls cassava whiteflies and viruses, and should be given attention in cassava whitefly and virus management programs.

\section{Adaptation strategies}

From this study, the important among relevant climate change adaptation strategies were integrating cassava pest and disease management programs, the use of resistant varieties, phytosanitation, the use of novel whitefly management techniques, biological control of whiteflies, and diversifying crop production. Similarly, these strategies were also recommended for climate change adaptation by Howden et al. (2007) (integrated pest management (IPM), resistant varieties, phytosanitation and quarantine, and diversifying crop production), Jones (2009) (IPM), Ceballos et al. (2011) (IPM, the use of resistant varieties, and biological control), Juroszek \& von Tiedemann (2011) (IPM, disease-resistant varieties, phytosanitation and quarantine, and diversifying crop production), Ghini et al. (2012) (disease-resistant varieties and the introduction of new control methods), Fahim et al. (2013) (IPM, disease and pest-resistant varieties, and the introduction of biological control organism), Kroschel et al. (2014) (IPM, disease and pestresistant varieties, phytosanitation and quarantine, the introduction of biological control organisms, and the introduction of new control methods) and Salaudeen et al. (2016) (IPM, virus-resistant varieties, and biological controls of the virus vectors).

Interestingly, a majority of these strategies have been deployed for the management of cassava pests in Africa (Neuenschwander et al., 2003; Legg \& Fauquet, 2004; Anderson \& Morales, 2005; Legg et al., 2006; IITA, 2012; Omongo et al., 2012; Fahim et al., 2013; Kroschel et al., 2014; Salaudeen et al., 2016; Legg et al., 2017; Legg et al., 2015, 2017; IITA, 2017). To maximize the opportunities for climate change adaptation, all barriers associated with the accessibility, availability, and adoption of these methods have to be addressed. This will involve increasing access to virus-free planting materials, increasing the use of virus and whitefly-resistant cassava planting materials, encouraging phytosanitation, and the use of available commercial whitefly biocontrol agents (which appear to be the most feasible strategies at the farm level). In the past, farmers have been supported in the deployment of IPM for the management of cassava pests (Neuenschwander et al., 2003; Anderson \& Morales, 2005; Legg et al., 2017). Additionally, regional or national initiatives on augmentative biological control and IPM programs for the control of cassava 
pests have been implemented (Anderson \& Morales, 2005). Encouraging these initiatives for climate change adaptation will be a further step in sustaining cassava production in the future.

\section{Measures to enhance adaptive capacity}

Considering the limited control of cassava whiteflies and the viruses they transmit, as shown in the study, more efforts and resources must be committed to enhancing the adaptive capacity of the farmers to decrease the possible impacts of cassava whiteflies and viruses due to climate change. Capacity building through the training of stakeholders, incorporating pest and disease adaptation planning into general agricultural management plans, establishing monitoring networks, and assessing adaptation needs through stakeholders emerged as the principal measures that can be deployed to enhance the adaptive capacity of smallholder farmers to lessen the impacts of cassava whiteflies and the viruses they vector due to climate change. These results are consistent with the findings and recommendations of other researchers (Smit et al., 2001; Brooks \& Adger, 2005; Howden et al., 2007; Lobell et al., 2008; Ingram, 2014; Kalaris et al., 2014; Legg et al., 2014b; Abdul-Razak \& Kruse, 2017; Osumanu et al., 2017; Macfadyen et al., 2018).

For instance, Abdul-Razak \& Kruse (2017) and Osumanu et al. (2017) from Ghana, emphasized the importance of training farmers and stakeholders in enhancing their adaptive capacities. Legg et al. (2014b) and Ingram (2014) suggested that training stakeholders will significantly contribute to reducing pest pressures and enhance the adaptive capacity of the farmers to limit the impacts of climate change. In highlighting the importance of pest surveillance and monitoring inenhancing climate change adaptation, Macfadyen et al. (2018) suggested that surveillance can guide the deployment and timing of pest control and also contribute to climate change adaption, while Kroshel et al. (2014) recommended establishing pest surveillance and regional networks on pest risks due to climate change. Monitoring cassava whiteflies and viruses is necessary for tracking changes at the regional and national levels, as well as estimating the success of regional pest management initiatives implemented to adapt to climate change. Surveillance programs can also facilitate the early detection and eradication of cassava viruses or B. tabaci species if they move into territories in which they were previously absent. Furthermore, Kalaris et al. (2014) argued that surveillance data may provide the basis for evaluating cost-benefit and management decisions. As shown in our findings, Macfadyen et al. (2018), Ingram (2014), Kroschel et al. (2012), and Kroschel et al. (2014) emphasized the importance of developing the capacity for pest risk forecasting in adapting to the impacts of climate change on crop pests and diseases.

Similar to our findings, Smit et al. (2001), Howden et al. (2007), Lobell et al. (2008), and Kroschel et al. (2014) also recommended building adaptive capacity through the incorporation of climate change adaptations (and in this case pest risk management due to climate change) into country climate resilience and the sustainable development plans. Smit et al. (2001) and Brooks \& Adger (2005) suggested that the assessment and prioritization of local adaptation needs and the provision of feedback to higher levels of government will enhance the adaptive capacity at the local scale.

\section{Conclusions}

In this study, we identified the production characteristics of smallholder cassava farmers and related it to adaptations to decrease the impacts of cassava whiteflies and viruses due to climate change. We then used expert judgments to identify adaptation strategies that might be deployed, measures to enhance the adaptive capacity of the farmers to lessen the impacts of cassava whiteflies and the viruses they transmit due to climate change. Based on the study, we concluded that the respondents were lowincome, small-scale farmers operating low-input but diversified cropping systems with limited deployment of control measures against cassava whiteflies and viruses. Food and economic security were their primary reasons for cassava production. In addition, several aspects of the farmers' production characteristics make them 
vulnerable to the impacts of cassava whiteflies and viruses due to climate change. Increased usage, modification, or intensification of existing cassava whitefly and virus management options, and deploying new methods when necessary will be important for adapting to the impacts of climate change on cassava whiteflies and viruses. Enhancing the adaptive capacity of the cassava farmers to the impacts of climate change on cassava whiteflies and viruses will require improving access to and the use of information, resources, technologies; engaging stakeholders, and putting up needed institutional and governmental support. The necessary strategies and technologies are already in place in Tanzania and other agro-ecologies across Africa. The challenge will be encouraging improved adoption of these strategies, tackling identified bottlenecks, and providing the needed resources, and institutional and governmental support. The results of this study will help farmers, governments, and institutional stakeholders in climate change adaptation planning and developing robust cassava pest management programs that will be useful for the management of the pests under current and future climate change scenarios. We recommend an appropriate level of commitment and investment geared at increasing access to resources (resistant planting materials, virus-free planting materials, biological control products, and extension services) and information as this will be a key to a more sustainable and food secure future.

\section{Acknowledgments}

The study was funded by the Education, Audio-visual and Culture Executive Agency of the European Commission through the Erasmus Mundus Joint Doctorate Fellowship (Agricultural Transformation by Innovation programme) awarded to Oluwatosin Zacheus Aregbesola. The contributions of James Peter Legg were supported by the CGAIR program on Root Tubers and Bananas.

\section{References}

Abdul-Razak M. \& Kruse S. (2017). The adaptive capacity of smallholder farmers to climate change in the
Northern Region of Ghana. Climate Risk Management. 17: 104-122.

Adhikari U., Nejadhashemi A. P. \& Woznicki S. A. (2015). Climate change and eastern Africa: A review of the impact on major crops. Food Energy Security. 4(2): 110-132.

Andersen J. R. (2017). Access to and benefit of agricultural extension in Tanzania a study from the Dodoma Region. Master Thesis University of Copenhagen (Denmark).

Anderson P. K. \& Morales F. J. (2005). Whitefly and whitefly-borneviruses in the tropics: Building a knowledge base for global action. Cali: Centro Internacional de Agricultura Tropical (CIAT).

Aregbesola O. Z. (2018). Understanding the potential impact of climate change on cassava-colonising whitefly, Bemisia tabaci (Gennadius) (Hemiptera: Aleyrodidae). PhD thesis the University of Catania, (Italy) and University of Copenhagen (Denmark).

Aregbesola O. Z., Legg J. P., Sigsgaard L., Lund O. S. \& Rapisarda C. (2019). Potential impact of climate change on whiteflies and implications for the spread of vectored viruses. Journal of Pest Science. 92: 381-392.

Aregbesola O. Z., Legg J. P., Lund O. S., Sigsgaard L., Sporleder M., Carhuapoma P. \& Rapisarda C. (2020). Life history and temperature-dependence of cassavacolonising population of Bemisia tabaci (Gennadius). Journal of Pest Science. DOI: 10.1007/s10340-02001249-z.

Asa U. A. \& Uwem C. A. (2017). Utilization of mobile phones for agricultural purposes by farmers in Itu area, Nigeria. European Science Journal. 13(19): 1-8.

Balama C., Augustino S., Eriksen S., Makonda F. S. B. \& Amanzi N. (2013). Climate change adaptation strategies by local farmers in Kilombero district, Tanzania. Ethiopian Journal of Environment Studies and Management. 6: 1-13.

Bellotti A., Campo B. V. H. \& Hyman G. (2012). Cassava production and pest management: present and potential threats in a changing environment. Tropical Plant Biology. 5(1): 39-72.

Brooks N. \& Adger W. N. (2005). Assessing and enhancing adaptive capacity. In Adaptation Policy Frameworks for Climate Change: Developing Strategies, Policies and Measures. Cambridge: Cambridge University Press: $165-181$.

Campo B. V. H., Hyman G. \& Bellotti A. (2011). Threats to cassava production: known and potential geographic distribution of four key biotic constraints. Food Security. 3(3): 329-345.

Ceballos H., Ramirez J., Bellotti A. C., Jarvis A. \& Alvarez E. (2011). Adaptation of cassava to changing climates. In: Yadav S. S., Redden R. J., Hatfield H. L., LotzeCampen H. \& Hall A. (Eds.). Crop Adaptation to Climate change. NewJersey: John Wiley and Sons: 411-425. 
Chongela J. (2015). Contribution of the agriculture sector to the Tanzania economy. American Journal of Research Communication. 3(7): 57-70.

Dubern J. (1994). Transmission of African cassava mosaic geminivirus by the whitefly (Bemisia tabaci). Tropical Science. 34: 82-91.

Fahim M. A., Hassanein M. K., Abolmaty S. M. \& Fargalla F. H. (2013). Challenges to crop pests and livestock diseases management in irrigated African agroecosystems under a changing climate. Researcher. 5(12): 129-138.

FAO - Food and Agricultural Organisation of the United Nations (2013). Cassava, a 21st-century crop. In Save and Grow: Cassava A guide to sustainable production intensification. Rome: FAO: 15-18.

Gamarra H., Mujica N., Carhuapoma P., Kreuze J. \& Kroschel J. (2016). Sweetpotato whitefly, Bemisia tabaci (Gennadius 1889) (Biotype B). In: Kroschel J., Mujica N., Carhuapoma P. \& Sporleder M. (Eds.). Pest distribution and risk atlas for Africa. Potential global and regional distribution and abundance of agricultural and horticultural pests and associated biocontrol agents under current and future climates. International Potato Center (CIP): 85-99. DOI: 10.4160/9789290604761-7.

Ghini R., Hamada E., Angelotti F., Costa L. B. \& Bettiol W. (2012). Research approaches, adaptation strategies, and knowledge gaps concerning the impacts of climate change on plant diseases. Tropical Plant Pathology. 37(1): 5-24.

Houngue J. A., Pita J. S., Todjro G. H., ZandjanakouTachin M., Abidjo E. A. E. \& Ahanhanzo C. (2018). Survey of farmers' knowledge of cassava mosaic disease and their preferences for cassava cultivars in three agro-ecological zones in Benin. Journal of Ethnobiology and Ethnomedicine. 14: 29. DOI: 10.1186/s13002-018-0228-5.

Howden S. M., Soussana J., Tubiello F. N., Chhetri N., Dunlop M. \& Meinke H. (2007). Adapting agriculture to climate change. Proceeding National Academy of Science. 104(50): 19691-19696.

Jarvis A., Ramirez-Villegas J., Campo B. V. H. \& NavarroRacines C. (2012). Is cassava the answer to African climate change adaptation? Tropical Plant Biology. 5(1): 9-29.

Jones R. A. C. (2009). Plant virus emergence and evolution: Origins, new encounter scenarios, factors driving emergence, effects of changing world conditions, and prospects for control. Virus Research. 141(2): 113-130.

Juroszek P. \& von Tiedemann A. (2011). Potential strategies and future requirements for plant disease management under a changing climate. Plant Pathology. 60(1): 100-112.

Kalaris T., Fieselmann D., Magarey R., Colunga-Garcia M., Roda A., Hardie D., Cogger N., Hammond N., Martin P. A. T. \& Whittle P. (2014). The role of surveillance methods and technologies in plant biosecurity. In: Gordh G. \& McKirdy S. (Eds.). The Handbook of Plant Biosecurity. Germany: Springer.

Kissoly L., Faße A. \& Grote U. (2018). Implications of smallholder farm production diversity for household food consumption diversity: insights from diverse agro-ecological and market access contexts in rural Tanzania. Horticulturae. 4: 14. DOI: 10.3390/horticulturae 4030014.

Kroschel J., Mujica N., Carhuapoma P., Juarez H., Okonya J., Le B. \& Hanna R. (2014). Adaptation to pest risks under future climates in Africa. Lima (Peru). CGIAR Research Program on Roots, Tubers and Bananas (RTB). RTB Workshop Report.

Komba C. \& Muchapondwa E. (2018). Adaptation to climate change by smallholder farmers in Tanzania. In: Berck C. S., Berck P. \& Di Falco S. (Eds.). Agricultural adaptation to climate change in Africa. Food security in a changing environment. UK: Taylor and Francis: 40.

Krone M., Schumacher K. P. \& Dannenberg P. (2014). The impact of mobile phones on knowledge access and transfer of small scale horticultural farmers in Tanzania. DIE ERDE. 145(3): 158-161.

Legg J., Okonya J. \& Coyne D. (2017). Integrated management of root and tuber crops in the Tropics. In: Rapisarda C. \& Coccuzza G. M. (Eds.). Integrated Pest Management in Tropical Regions. UK: CAB International: 90-112.

Legg J. P., Kumar P. L., Makeshkumar T., Tripathi L., Ferguson M., Kanju E., Pheneas N. \& Cuellar W. (2015). Cassava Virus Diseases: Biology, Epidemiology, and Management. Advances in Virus Research. 91: 85-142.

Legg J. P., Shirima R., Tajebe L. S., Guastella D., Boniface S., Jeremiah S. C., Nsami E., Chikoti P. \& Rapisarda C. (2014b). Biology and management of Bemisia whitefly vectors of cassava virus pandemics in Africa. Pest Management Science. 70: 1446-1453.

Legg J. P., Sseruwagi P., Boniface S., Okao-Okuja G., Shirima R., Bigirimana S., Gashaka G., Herrmann H. W., Jeremiah S., Obiero H. \& Ndyetabula I. (2014a). Spatio-temporal patterns of genetic change amongst populations of cassava Bemisia tabaci whiteflies driving virus pandemics in East and Central Africa. Virus Research. 186: 61-75.

Legg J. P. \& Fauquet C. M. (2004). Cassava mosaic geminiviruses in Africa. Plant Molecular Biology. 56(4): 585-599.

Legg J. P. \& Raya M. (1998). A survey of cassava virus diseases in Tanzania. International Journal of Pest Management. 44: 17-23.

Lobell D. B., Burke M. B., Tebaldi C., Mastrandrea M. D., Falcon W. P. \& Naylor R. L. (2008). Prioritizing Climate Change Adaptation Needs for Food Security in 2030. Science. 319: 607-610.

Lyimo J. G., Ngana J. O., Liwenga E. \& Maganga F. (2013). Climate change, impacts and adaptations in the 
coastal communities in Bagamoyo District, Tanzania. Environmental Economics. 4(1): 63-71.

Macfadyen S., McDonald G. \& Hill M. P. (2018). From species distributions to climate change adaptation: Knowledge gaps in managing invertebrate pests in broad-acre grain crops. Agriculture, Ecosystem and Environment. 253: 208-219.

Makate C., Wang R., Makate M. \& Mango N. (2016). Crop diversification and livelihoods of smallholder farmers in Zimbabwe: adaptive management for environmental change. SpringerPlus 5(1): 1135. DOI: 10.1186/s40064-016-2802-4.

Maruthi M. N., Hillocks R .J., Mtunda K., Raya M. D., Muhanna M., Kiozia H., Rekha A. R., Colvin J. \& Thresh J. M. (2005). Transmission of cassava brown streak virus by Bemisia tabaci (Gennadius). Journal of Phytopathology. 153: 307-312.

Mary A. L. \& Majule A. E. (2009). Impacts of climate change, variability and adaptation strategies on agriculture in semi-arid areas of Tanzania: The case of Manyoni District in Singida Region, Tanzania. African Journal of Environmental Science and Technology. 3(8): 206-218.

Niang I., Ruppel O. C., Abdrabo M. A., Essel A., Lennard C., Padgham J. \& Urquhart, P. (2014). Africa. In: Barros V. R., Field C. B., Dokken D. J., Mastrandrea M. D., Mach K. J., Bilir T. E., Chatterjee M., Ebi K. L., Estrada Y. O., Genova R. C., Girma B., Kissel E. S., Levy A. N., MacCracken S., Mastrandrea P. R. \& White L. L. (Eds.). Climate Change 2014: Impacts, Adaptation, and Vulnerability. Part B: Regional Aspects. Contribution of Working Group II to the Fifth Assessment Report of the Intergovernmental Panel on Climate Change. Cambridge and New York, USA: Cambridge University Press: 1199-1265.

Neuenschwander P., Borgemeister C. \& Langewald J. (2003). Biological control in IPM systems in Africa. Wallingford: CAB International.

Ndyetabula I. L., Merumba S. M., Jeremiah S. C., Kasele S., Mkamilo G. S., Kagimbo F. M. \& Legg J. P. (2016). Analysis of interactions between cassava brown streak disease symptom types facilitates the determination of varietal responses and yield losses. Plant Disease. 100(7): 1388-1396.

Oleke J. M., Isinika A., Manyong V., Hanna R. \& Sabelis M. (2012). Farmers' perception of coconut mite damage and crop diversification alternatives in the coastal belt of Tanzania. International Journal of Acarology. 38(6). DOI: 10.1080/01647954.2012.682093.

Olsen W. (2004). Triangulation in social research:
Quantitative and qualitative methods can really be mixed. In: Ormskirk H. M. (Ed). Development in Sociology. Causeway Press: United Kingdom: 103-118.

Omolehin R. A., Ogunfiditim T. O. \& Adeniji O. B. (2007). Factors influencing the adoption of chemical pest control in cowpea production among rural farmers in Makarfi Local Government Area of Kaduna State, Nigeria. International Journal of Agricultural Research. 2(11): 920-928.

Osei M. K., Taah K. J., Berchie J. N. \& Osei C. K. (2009). A survey of cassava (Manihot esculenta Crantz) planting materials in storage: A case study in two communities in the Ejisu District of Ashanti Region, Ghana. Journal of Agronomy. 8: 137-140.

Osumanu I. K., Aniah P. \& Yelfaanibe A. (2017). Determinants of adaptive capacity to climate change among smallholder rural households in the Bongo District, Ghana. Ghana Journal of Development Studies. 14(2): 1-22.

Oyekanmi A. A. \& Okeleye K. A. (2007). Cassava production systems across some agro-ecological zones in South West North West Axis of Nigeria. Asian Journal of Plant Science 6: 158-162.

Salaudeen M. T., Adama C. J., Abdullahi A. A., Ayeleke D. A. \& Ibrahim A. D. (2016). Climate change and viral diseases in relation to crop productivity and food security: A review. International Journal of Applied Biology Research. 7(1): 56-65.

Smit B., Pilifosova O., Burton I., Challenger B., Huq S., Klein R. J. T., Yohe G., Adger N., Downing T., Harvey E., Kane S., Parry M., Skinner M., Smith J., Wandel J., Patwardhan A. \& Soussana J. F. (2001). Adaptation to climate change in the context of sustainable development and equity. In: McCarthy J. J., Canziani O. F., Leary N. A., Dokken D. J. \& White K. S. (Eds.). Climate change 2001: impacts, adaptation, and vulnerability. Contribution of Working Group II to the Third Assessment Report of the Intergovernmental Panel on Climate Change. Cambridge: Cambridge University Press: 877-912.

The URT-United Republic of Tanzania (2012a). National sample census of agriculture 2007/2008 smallholder agriculture volume II: crop sector - national report. Tanzania: Government of Tanzania.

URT (2012b). National sample census of agriculture 2007/2008 volume VG: regional report: - Dar es Salaam Region. Tanzania: Government of Tanzania.

Uwagboe E. O., Akibile L. A., Oduwole O. O. (2012). Socio-economic factors and integrated pest management utilization among cocoa farmers in Edo State. Academic Journal of Plant Science. 5(1): 7-11. 